\title{
922 粒子法を用いた 3 次元流路を流れる赤血球の変形シミュレーション Three-Dimensional Simulation of RBC Deformation in a Flow Vessel using MPS Method
}

\author{
○学 田中正幸(東京大) 正 越塚誠一(東京大) \\ Masayuki Tanaka, Seiichi Koshizuka \\ Department of Quantum Engineering and Systems Science, The University of Tokyo, \\ Hongo 7-3-1, Bunkyo, Tokyo 113-8656
}

Key Words : Red Blood Cell, Deformability, MPS method, Spherocyte, Spleen

\section{1. 序論}

正常な赤血球は静止流体中において両凹円盤形をしてい るが、非常に大きな変形能を持ち、流れの中ではカップ形 状となって流れ、自身よりも細い毛細血管をも容易に通過 することができる。その赤血球には様々な病気があること が知られている。

遺伝性球状赤血球症は赤血球膜に異常が起き赤血球が球 状や棈円状になる病気であり、これらの赤血球は変形能が 低く脾臟を通過できない場合がある。その結果貧血や脾臓 が非常に大きくなってしまう脾腫が引き起こされる。

和田らは赤血球膜のモデルとしてバネモデルを適用する ことにより両凹円盤形を再現することに成功した ${ }^{1)}$ 。また、 坪田ら ${ }^{2}$ や田中ら ${ }^{3}$ ( は赤血球の変形と流れの相互作用の研 究を行っている。過去の研究において 2 種類のバネ定数の 值を変えることにより両凹円盤形や球形、回転棈円体形な ど様々な形に変形することが確認されている。そこで、本 研究ではこれらの症状の原因を力学的に解明するため、 MPS 法を用いて赤血球のモデル化、および流路中の変形シ ミュレーションを行った。

\section{2. シミュレーション手法}

\subsection{MPS 法}

本研究では流体を粒子法の 1 つである MPS (Moving Particle Semi-implicit）法を用いて解析する。MPS 法では 粒子数密度

$$
w(r)= \begin{cases}\frac{r_{e}}{r}-1 & r \leq r_{e} \\ 0 & r_{e}<r\end{cases}
$$

を用いて連続体の運動を有限個の粒子の運動として離散化 する。勾配モデル、ラプラシアンモデルはそれぞれ次のよ うに表される。

$$
\begin{gathered}
\frac{\partial \vec{u}_{i}}{\partial t}=-\frac{d}{\rho n^{0}} \sum_{j \neq i}\left[\frac{P_{j}-P_{i}}{\left|\vec{r}_{j}-\vec{r}_{i}\right|^{2}}\left(\vec{r}_{j}-\vec{r}_{i}\right) w\left(\left|\vec{r}_{j}-\vec{r}_{i}\right|\right)\right] \\
<\nabla^{2} \phi>_{i}=\frac{2 d}{n^{0} \lambda} \sum_{j \neq i}\left[\left(\phi_{j}-\phi_{i}\right) w\left(\left|\vec{r}_{j}-\vec{r}_{i}\right|\right)\right]
\end{gathered}
$$

非圧縮条件は粒子数密度一定として表現される。赤血球粒 子も流体として扱うものとする。

\section{2 赤血球䀧のバネモデル}

赤血球膜変形 2) に関して、膜を構成する粒子を三角格子

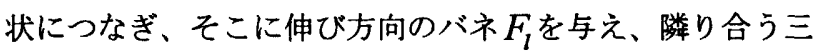
角形間に曲げ方向のバネ $F_{b}$ を与えた(図 1$) 。$

$$
\begin{aligned}
& F_{l}=k_{l}\left(l-l_{0}\right) \\
& F_{b}=k_{b} \tan \left(\frac{\theta}{2}\right)
\end{aligned}
$$

ここで、 $l_{0}$ は初期状態における粒子間距離の平均值であり、 $l_{0}=1.0 \times 10^{-6}[\mathrm{~m}]$ とした。 $\theta$ は隣り合う膜面の法線べクト ルの成す角である。

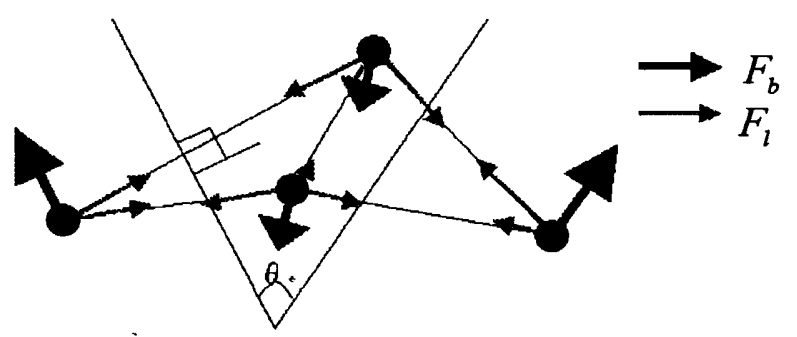

図 1 バネによる赤血球膜モデル

球形を初期状態とした赤血球膜に上記のバネの力を適用 しつつ体積を減少させると 2 種類のバネ定数の組み合わせ により、両凹円盤状、球状、回転楕円体状、カップ状など の形状となる。それぞれの形状となるバネ定数の值は図 2 の通りである。ここで、代表長さ $l_{0}$ を用いて以下のような 無次元数 $\gamma$ を定義する。図中の赤線は $y=1.0$ を表している。

$$
\gamma=\frac{k_{l}}{k_{b}} l_{0}
$$

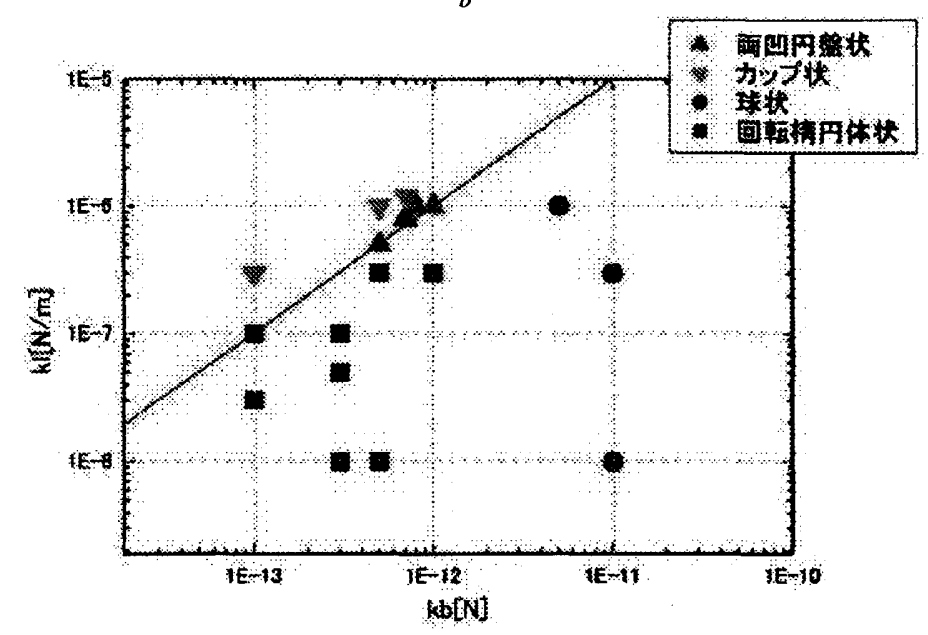

図 2 バネ定数と形状の関係

本研究では $k_{l}=1.0 \times 1.0^{-6}[\mathrm{~N} / \mathrm{m}] 、 k_{b}=1.0 \times 1.0^{-12}[\mathrm{~N}]$ を正常 な赤血球を表すバネ定数であるとする。

〔No.05-2〕日本機械学会第 18 回計算力学講演会講演論文集 〔2005-11.19 21・つくば市 


\section{3 シミュレーション条件}

両凹円盤形の赤血球を初期状態とし、一様な流路と一部 が細くなっている流路の二種類の流路に流す。両凹円盤形 の赤血球を流路に対して垂直に配置し、右向きに重力を与 えることにより流速を生じさせた。それぞれの流路の断面 図を図 3、図 4 に示す。なお、青い粒子が流体、黄色い粒子 が壁、赤い粒子が赤血球を表しており、流路全体の粒子数 は約 5500 個、その内赤血球膜粒子が 186 個、赤血球内部粒 子が 121 個となっている。

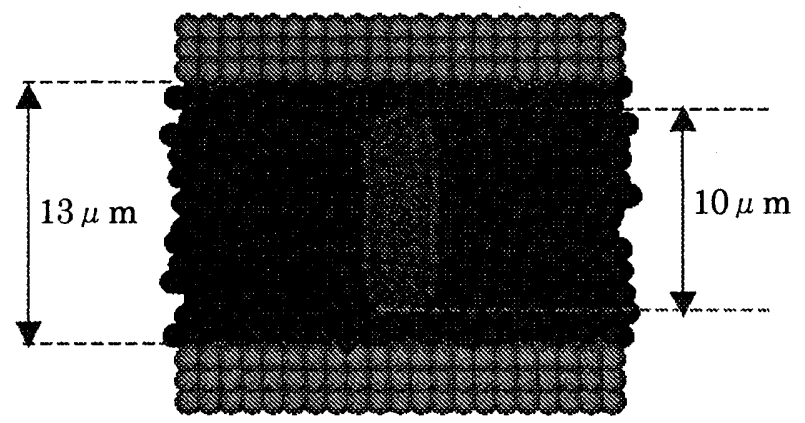

図 3 一様な流路の断面図

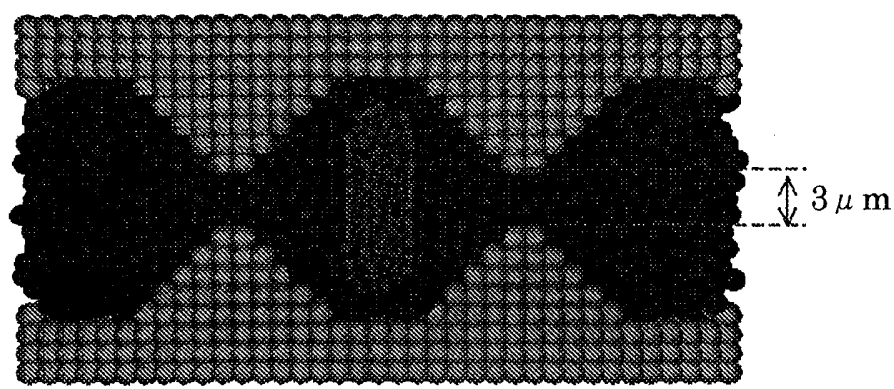

図 4 一部が細くなっている流路の断面図

\section{3. 解析結果と考察}

まず正常な赤血球が一様な流路を流れる様子を図 5 に示 す。ただし、流体粒子および赤血球内部粒子は可視化して いない。赤血球よりも大きな流路を流れる場合、赤血球は 片側だけが凹んだカップ状となった。

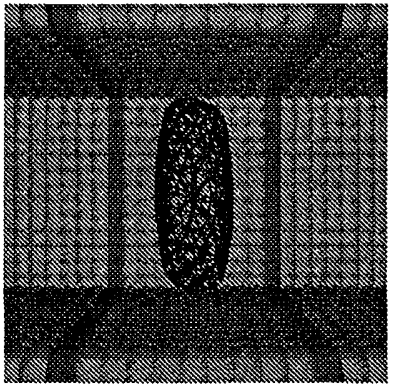

(a) 0.0 秒後

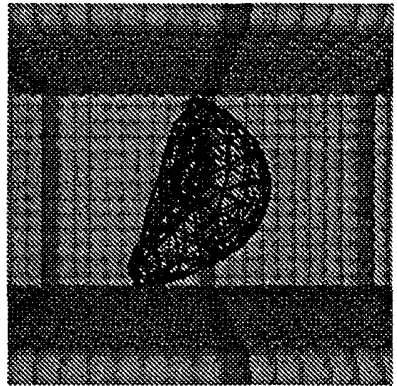

(b) 0.050 秒後
図 5 流路を流れる正常赤血球

図 6 は正常な赤血球が自身の大きさよりも細い流路を流 れる様子である。上記同様最初はカップ状に変形し、その 後大きく変形しながら細い部分を通過する。通過し終わる と元のカップ状に戻る。

また、 $k_{l}=1.0 \times 1.0^{-6}[\mathrm{~N} / \mathrm{m}] 、 k_{b}=1.0 \times 1.0^{-11}[\mathrm{~N}]$ の場合に ついても同様の解析を行った。これは正常赤血球よりも曲 げ方向のバネを強くしたものであり、球状赤血球となり、 変形能が低く、流路の細い部分で詰まってしまう(図 7)。

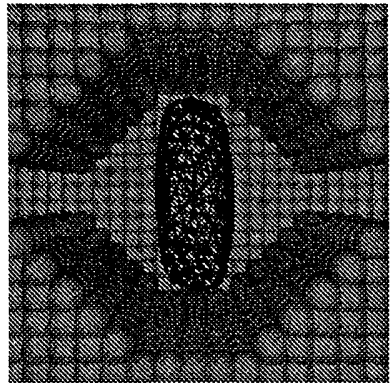

(a) 0.0 秒後

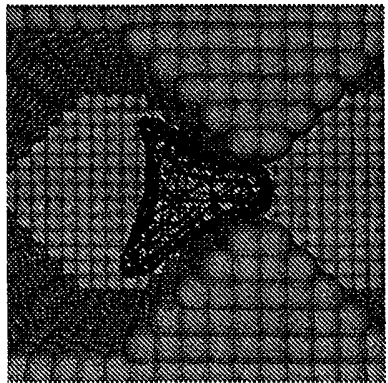

(c) 0.030 秒後

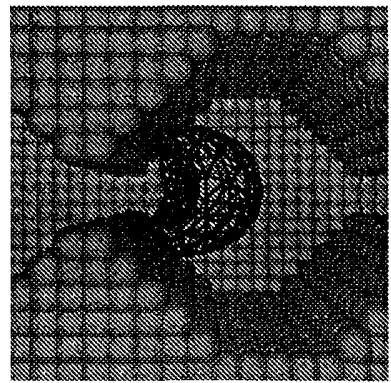

(e) 0.055 秒後

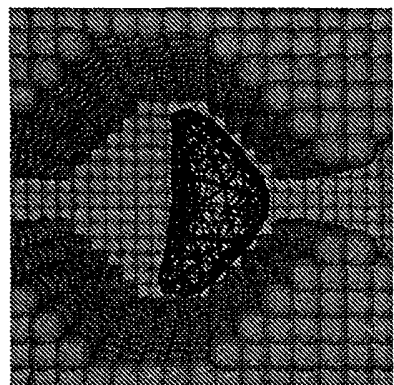

(b) 0.015 秒後

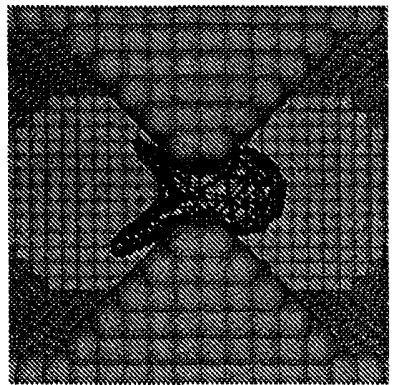

(d) 0.040 秒後

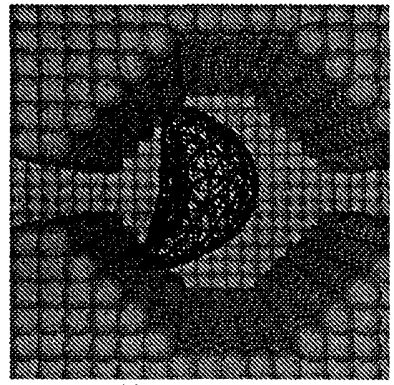

(f) 0.070 秒後
図 6 自身よりも細い流路内を通過する正常赤血球

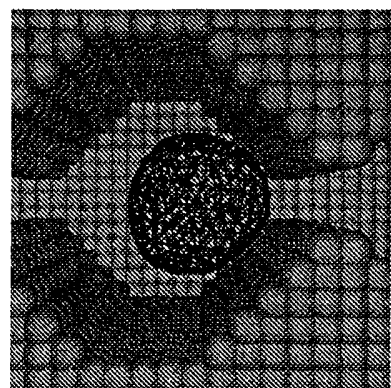

(a) 0.015 秒後

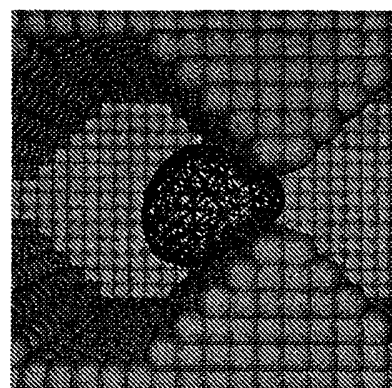

(b) 0.060 秒後
図 7 球状赤血球が詰まる様子

\section{4. 結論}

赤血球膜にバネモデルを適用することにより、流路内を 流れる様子と自身よりも狭い流路を変形しながら通過する 様子、球状赤血球が細い流路で詰まってしまう様子を解析 することができた。今回の研究では曲げ方向のバネを強く した場合のみ比較を行ったが、伸び方向のバネも含めバネ の強さと変形能の関係を明らかにし、脾臓を通過する赤血 球の挙動を解析することが今後の課題である。

\section{参考文献}

1）和田ら,機論 $A, 69$ 巻 677 号,14-21(2003).

2) 坪田ら，機講論，No.04-48(2005), 241-242.

3）田中ら, 機講論, No.03-26(2003), 295-296. 